Int. J. Electrochem. Sci., 11 (2016) $8827-8847$

\title{
Corrosion Inhibition of Low Carbon Steel by Strychnos nux- vomica Extract as Green Corrosion Inhibitor in Hydrochloric Acid Solution
}

\author{
N. Soltani ${ }^{*}$, N. Tavakkoli, M. Ghasemi \\ Department of Chemistry, Payame Noor University, P.O. Box 19395-3697 Tehran, Iran \\ "E-mail: nasrin.soltani@pnu.ac.ir, nasrin_soltani2056@yahoo.com
}

doi: $10.20964 / 2016.10 .22$

Received: 1 April 2016 / Accepted: 4 August 2016 / Published: 6 September 2016

\begin{abstract}
In this study, the inhibition action of Strychnos nux-vomica extract on the corrosion of carbon steel in 4 $\%$ and $8 \% \mathrm{HCl}$ solution has been investigated in different temperatures. For this purpose, the methods of weight loss, electrochemical impedance spectroscopy (EIS) and potentiodynamic polarization were used for investigation of performance of Strychnos nux-vomica extract in ambient temperature, while potentiodynamic polarization method was also used at different temperatures to define the effect of temperature on the inhibition efficiency of Strychnos nux-vomica extract. The obtained results demonstrate that inhibition efficiency in both media increased with increasing concentrations and decreases with increasing temperature. The polarization curves revealed that Strychnos nux-vomica extract represent mixed-type behavior in both $4 \%$ and $8 \% \mathrm{HCl}$ solution. At all temperatures, the adsorption of the extract components onto the steel surface was followed Langmuir adsorption isotherm. Quantum chemical calculations were done to predict the adsorption of main components of Strychnos nux-vomica extract on the metal surface.
\end{abstract}

Keywords: Carbon steel; Weight loss; EIS; Polarization; Acid corrosion; Strychnos nux-vomica extract.

\section{FULL TEXT}

(C) 2016 The Authors. Published by ESG (www.electrochemsci.org). This article is an open access article distributed under the terms and conditions of the Creative Commons Attribution license (http://creativecommons.org/licenses/by/4.0/). 